\title{
Effect of Carbon Emission Disclosures on Sustainability of Oil and Gas Firms in Nigeria
}

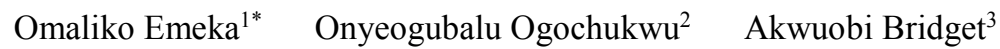 \\ 1.Department of Accountancy, Faculty of Management Sciences, Nnamdi Azikiwe University, Awka, Nigeria, \\ P.M.B. 5025 Awka
}

\begin{abstract}
The study examines the effect of Carbon Emission Disclosures on Sustainability of Oil and Gas Firms in Nigeria. The study is vital as it portrays the extent to which Carbon Emission Disclosures influence firms' Sustainability in Nigeria. In order to determine the relationship between Carbon Emission Disclosures and Firms Sustainability, some key proxy variables were used in the study, namely; Leverage and Firms Size as a measurement for sustainability while Carbon Emission Disclosures was measured using the GRI G4 Disclosure Index. Two hypotheses were formulated to guide the investigation and the statistical test of parameter estimates was conducted using OLS Regression Model. The research design used is Ex Post Facto design and data for the study were obtained from the NSE Factbook, Annual Reports \& Accounts and Sustainability Reports of oil and gas firms in Nigeria spanning from 2015-2020. The findings of the study generally indicate that Carbon Emission Disclosures have significant and positive effect on Firms Sustainability in Nigeria at 1\% level of significance. Based on the findings of the study, it was recommended that corporate organizations should be social responsible and environmental friendly since environmental friendly and social responsible firms are more sustainable. Also sustainability of a company's current life is largely determined by the company's ability to manage social and environmental performance.
\end{abstract}

Keywords: Carbon Emission Disclosure, Leverage, Firms Size, Sustainability

DOI: $10.7176 / \mathrm{JESD} / 12-20-02$

Publication date:October $31^{\text {st }} 2021$

\subsection{Introduction}

Global warming has been a major and topical issue that attracts attention and public concerns towards disasters it caused that could jeopardize the life of living creatures which remains a global burning issue. The National Aeronautics and Space Administration (NASA), observed that earth temperature has uninterruptedly increased from January to September 2016, while the earth temperature has touched the warmest level for 35 years. Definitely, global warming is a phenomenon of snowballing global temperature because of greenhouse gas effect produced by increased emissions of gases such as carbon dioxide $(\mathrm{CO} 2)$, methane $(\mathrm{CH} 4)$, chlorofluorocarbons (CFC) and dinitrogen oxide (N2O), which cause solar energy being trapped in the atmosphere (Riebeek 2010).

The increasing danger in global warming is driven by greenhouse gas emissions produced by human actions. However, $\mathrm{CO} 2$ emission released through human activities has been the most dangerous increase in greenhouse gases, such as deforestation, fossil fuel use, increased industrial quantities and natural processes including respiration and volcanic eruptions. Undesirably, our planet capability to process this waste has been greatly deteriorated by widespread of more destruction of the world's forests. Based on this, there are high carbon emissions in Nigeria which are not equivalent with the disclosure of the environment in Nigeria companies. World Bank through low-carbon development shows that Nigerian companies have low environmental disclosure with average of $20 \%$ on oil and gas companies' carbon emissions disclosure which calls for reinvestigation.

World Resources Institute (WRI) on its official website stated that Nigeria ranks 90th world largest contributing country of carbon emissions in 2019, after United States, European Union, China, India and Russia. This phenomenon caused the perceptibility of awareness of business actors towards environmental. The environmental impacts of the company's activities have been regulated by the Financial Accounting Standards. The oil and gas sector has historically been one of the main sources of greenhouse gas (GHG) emissions in Nigeria. Estimated annual emissions in 2010 were approximately 90 million metric tons carbon dioxide equivalent (Mt $\mathrm{CO} 2 \mathrm{e}$ ) per year, of which the dominant source is gas flaring. The other major sources are on-site use of gas (mainly for power generation) for operating oil and gas production, transportation, and processing facilities; fugitive emissions of gas through leaks and other losses; and venting of gas from oil reduction. Under the low-carbon scenario, GHG emissions are significantly reduced, with better utilization of Nigeria's gas resources through reduced waste of AG. The total potential abatement over the 2010-35 period is estimated to be $750 \mathrm{Mt}$ CO2e (Raffaello, John \& Max, 2013).

However, carbon emissions disclosure practice in Nigeria is mainly voluntary disclosure. According to Omaliko, Nwadialor and Nweze (2020), carbon emission disclosures has attracted considerable interest from a number of key stakeholders such as the United Nations Global Compact, the Global Reporting Initiative (GRI), the International Integrated Reporting Council (IIRC), the Sustainability Accounting Standards Board (SASB), 
the Task Force on Climate-related Financial Disclosures (TFCD) and European Commission Guidelines.

Previous research on carbon emission disclosures in both developed and developing nations showed inconsistent and mixed results. Thus, researchers are interested to elaborate more on the subject matter especially in the developing nations were little or no study had concentrated on. For instance, Bae, Lee and Psaros (2013) reported that leverage and profitability are not affected by carbon emissions disclosure, while firm size, industry type, carbon emission level, and quality of corporate governance have significant relation with carbon emission disclosure. Similar result was gotten from the work of Jannah and Muid (2014) who analyzed factors that influence carbon emission disclosure in Indonesian companies. The study found that carbon emission disclosure has negative impact on firms leverage. Moreover, environmental performance in their study demonstrated no significant association with carbon emissions disclosure.

Akhiroh and Kiswanto (2016) on the same note executed a research on determinant of carbon emission disclosure. Results indicated that profitability, organizational visibility, managerial ownership and audit committee have significant and positive association with carbon emission disclosures, while environmental performance, financial distress, institutional ownership, and independent commissioners have no association with carbon emission disclosure. Also, Omaliko and Okpala (2020) reported that environmental friendly firms are more sustainable and also pay higher dividend than non environmental friendly firms. Thus, conflicting and mixed results were found on the impact of carbon emission disclosures on firms' characteristics which calls for further clarity.

Also some corporations in developing countries are becoming conscious of their international market and are creating appreciable effort especially as regards to environmental practices. The result of sampled industries in Nigeria shows that few companies are becoming social responsible and environmental friendly (Omaliko Nweze and Nwadialor, 2020). However a large number of firms are still apathetic about their environmental and social responsibility as they are unaware of the connection between carbon emission disclosures and their performance.

Based on this observation, this study considered it imperative to examine the relationship between carbon emission disclosures and firms sustainability. Thus, the study examined the effect of carbon emission disclosure on sustainability of oil and gas firms in Nigeria with data spanning from 2015-2020 which no recent study had focused on.

\subsection{Objective of the Study}

The aim of this study is to examine the effect of carbon emission disclosures on sustainability of oil and gas firms in Nigeria. The specific objectives include; to

1. determine the effect of Carbon Emission Disclosures on Leverage of oil and gas Firms in Nigeria.

2. ascertain the effect of Carbon Emission Disclosures on Size of oil and gas Firms in Nigeria.

\subsection{Research Questions}

Three research questions established for the study is as follows:

1. To what extent does Carbon Emissions Disclosures affect the Leverage of oil and gas firm in Nigeria?

2. What is the effect of Carbon Emission Disclosures on Size of oil and gas firms in Nigeria?

\subsection{Research Hypothesis}

In order to direct the direct flow of this study, the following hypothesis were formulated in line with objectives of the study

H01: Carbon Emission Disclosures has no significant effect on Leverage of oil and gas firm in Nigeria.

$\mathbf{H}_{02}$ : Carbon Emission Disclosures has no significant effect on the Size of oil and gas firm in Nigeria.

\subsection{Review of Related Literature}

\subsubsection{Carbon Emission Disclosure}

According to Carbon Emissions and Greenhouse Gases Based on the United States Environmental Protection Agency (EPA), is a disclosure on greenhouse gas which is a gas that may be trapping heat in the earth's atmosphere so that the heat of the sun reflected by the earth's surface is caught by the gas and cannot get out of the atmosphere. The buildup of these gases makes the rising rays infrared reflected earth and lead to a rise in temperature of the earth's surface. These gases include carbon dioxide (CO2), methane (CH4), dinitrogen oxide (N2O), hydrofluorocarbon (HFC), perfluorocarbon (PFC), and sulfur hexafluoride (SF6). Carbon emissions are distinguished into two, namely the natural carbon gas and the carbon gas, which comes from human activities, or may also be referred to as the carbon gas industry (Gayo \& Vera, 2020).

According to Ecolife.com, carbon emissions are carbon release to the atmosphere. It is associated with greenhouse gas emissions, the main contributor to climate change. $\mathrm{CO} 2$ emissions from time to time continue to increase both at the global, regional, national to a state or local to an area. This happens because of the growing use of energy from organic materials (fossil), land use change and forest fires, as well as the increase in 
anthropogenic (Diah \& Efita, 2016). The study also noted that one contributor to the carbon footprint is the operational activities of the company. Companies in the face of climate change are expected to disclose their activities that contribute to the improvement of climate change. Such disclosures are referred to as carbon emission disclosure.

According to Mohammad, Aisa and Indah (2020), companies' carbon emission disclosures include community environment, business environment, and government pressuring the companies to respond to the threats of environmental sustainability resulting from the effects of extreme climate changes. Companies can respond to this demand by disclosing the carbon emissions produced from their operational activities. The stakeholders may consider that carbon emission disclosure is a form of corporate responsibility in responding to the demand for reducing the impacts of environmental damage.

\subsubsection{Leverage}

Financial leverage can be described as the extent to which a business or investor is using borrowed money. Leverage is a measure of how much firm uses equity and debt to finance its assets. As debt increases, financial leverage also increases. It has also been seen in different studies that financial leverage has relationship with financial performance (Sayed, 2013).

\subsubsection{Firm Size}

The nature of the relationship between firm size and financial performance has received considerable attention in the literature and has motivated strong debate. Several arguments favor larger firm size in attaining higher performance. Large firms are more likely to exploit economies of scale and enjoy higher negotiation power over their clients and suppliers (Serrasqueiro \& Nunes).

\subsubsection{Conceptual Model}

Independent Variable

Dependent Variables

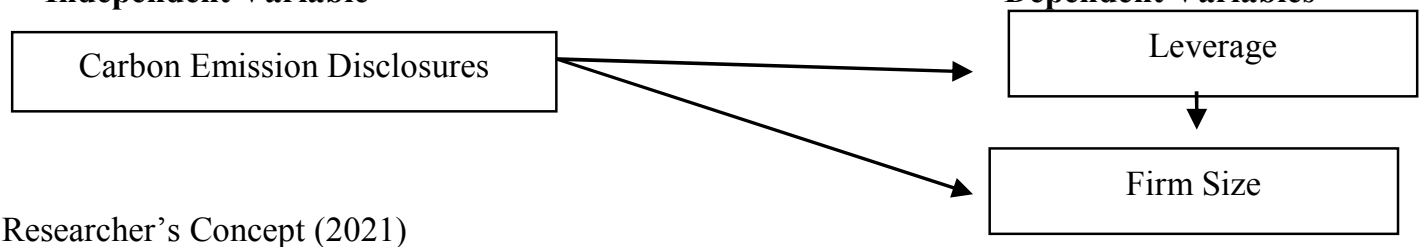

Source: Researcher's Concept (2021)

\subsection{Theoretical Framework}

\subsubsection{The Legitimacy Theory}

This study employs legitimacy theory as a theoretical framework. This theory was propounded by Donavan in the year 1984. The legitimacy theory presents two basic ideas whereby corporate organizations need to legitimize their activities and this legitimacy process provides benefits to the organization. Disclosing Quality Non Financial Information is a way for companies to legitimize their activities which in this regard is carbon emission disclosures. The benefit from the legitimacy process is represented on firm's sustainability. Legitimacy theory presumed that a corporation will act to ensure that its activities and actions were congruent with whom it believed has the necessary attributes to affect the corporation's image and ultimately, existence (Donavan, 1984).

Suchman (1995) described legitimacy theory as a generalized perception or assumption that the actions of an entity are desirable, proper, or appropriate within some socially constructed system of norms, values, beliefs and definitions. Using the legitimacy perspective, firms voluntarily disclose carbon emission disclosures to show that they are conforming to the expectations and values of the society within which they operate. According to Guthrie and Parker (2009), they argue that if the legitimacy explanation holds true, the corporate disclosure policies will react to major social and environmental events.

On the other hand, the theory suggests that social expectations no longer rests upon mere generation of profit but has broadened to include local communities as well as concern for the natural environment. Therefore, firms need to provide voluntary information to meet the broad expectations of society relating to the treatment of the natural environment. Hence the study is anchored on Legitimacy theory.

Also Information asymmetry occurred when management has information on a company that is not owned by an outsider. Therefore, companies are expected to make voluntary disclosures about company information, such as environmental issues which in this case is carbon emissions disclosure. By doing this, it is expected to minimize information asymmetry between agents and principals.

\section{Empirical Studies}

Healy and Palepu (2001) claimed that voluntary disclosure by companies can improve their financial statements quality; therefore, potential investors are willing to invest. When a company discloses its carbon emissions, then it can be considered responsible for its environment. As such, the company is able to increase its stakeholders' confidence, which will also increase its business profit that ensures sustainability. This study explains that the more companies in Indonesia disclose their carbon emissions, the more they will be considered capable to utilise their energy resources efficiently, by reducing greenhouse gas emissions and protecting ecological balance. 
In Indonesia, study conducted by Siregar and Deswanto (2018) found that environmental disclosures do not affect the firm value. Saka and Oshika (2014) examined the interaction between GHG emissions disclosure and environmental performance on firm value. The study found that the greater the volume of GHG emissions (environmental performance), the stronger the positive effect of GHG emissions disclosure on firm value.

According to Ennis, Kottwitz, Lin and Markusson (2012), companies that disclose their carbon emissions should enable the stakeholders to make decisions regarding the companies' condition of carbon emissions performance, encourage companies to reduce their carbon emissions, give contribution to public debates of policies, as well as regulations on climate change. Anggraeni (2015) showed that environmental performance does not affect the relationship between GHG emissions disclosure and firm value. Based on the explanation, this study assumes that the PROPER rating can moderate the effect between GHG information disclosure and firm value.

Cucchiella, Gastaldi, and Miliacca (2017) argue that good environmental management activities (waste management, water consumption, controlling GHG emissions, refining waste and so on) can lead to saving firms' resources, increasing productivity and income, and ultimately the value of the firm. The sample of research by Bae, Lee and Psaros (2013), on carbon emissions disclosure in Australian companies showed that leverage and profitability are not affected by carbon emission disclosures, while firm size, industry type, carbon emission level, and quality of corporate governance have significant association with carbon emission disclosure.

Similar result was gotten from the work of Jannah and Muid (2014) who analyzed factors that influence carbon emission disclosure in Indonesian companies. The study found that leverage has significant and negative effect on carbon emission disclosure, whereas firm size, profitability, media exposure and industry type have significant and positive impact. Additionally, environmental performance in their study demonstrated no significant effect on carbon emissions disclosure.

Akhiroh and Kiswanto (2016) executed a research on determinant of carbon emission disclosure. Results indicated that profitability, organizational visibility, managerial ownership and audit committee have significant and positive association with carbon emission disclosures, while environmental performance, financial distress, institutional ownership, and independent commissioners have no association with carbon emission disclosures.

Lee and Min (2015) evaluated the effect of green research and development investment on environmental and financial performance using Japanese manufacturing companies (from 2001 to 2010). The study reported a negative relationship between green research and development investment and carbon emissions. The study concluded that companies must control emissions to acquire high financial performance.

Gallego-Álvarez, Segura, Martínez-Ferrero (2015) examined the influence of carbon emissions on corporate financial performance of 89 companies for the period 2006-2009 and posited that a reduction of carbon emissions increased corporate financial returns.

Omaliko and Okpala (2020) examined the effect of environmental disclosures on dividend payout of firms in Nigeria. Using regression model, the study found that environmental friendly firms are more sustainable and also pay higher dividend than non environmental friendly firms.

\subsection{Methodology}

The research design used in this study is Ex Post Facto Design. Ex Post Facto Design was used in order to examine the effect of carbon emission disclosures on sustainability of oil and gas Firms quoted on Nigerian Stock Exchange (NSE). Oil and gas firms quoted on Nigerian Stock Exchange (NSE) which engaged on downstream activities and as well disclose carbon emission during 2015-2020 is 12 in number as at 2021 business list. It ranges from Ardova Plc, Conoil Plc, Oando Plc, Japaul Oil Plc, Seplat Oil Plc, Mrs Oil Plc, Total Oil Nig Plc, Amino International Plc, Rak Unity Pet Plc, Capital Oil Plc, 11 Plc to Eternal Plc.

Data for the study were obtained from the NSE Factbook, Annual Reports \& Accounts and Sustainability Reports of the firms. The collected data were analyzed OLS Regression Model using SPSS Statistical package V.20

\subsection{Operationalization and Measurement of Variables}

The dependent variable in this study is leverage and firm size and it were proxy using the variables as shown on the table below:

Table 1: Variable Measurements

\begin{tabular}{|c|c|c|}
\hline S/N & VARIABLES & FORMULA \\
\hline & Dependent & LEV: Total Debts / Total Assets \\
\hline 1 & Leverage & FS: Log of Total Assets \\
\hline 2 & Firm Size & Independent \\
\hline 1 & Carbon Emission Disclosure & Measured based on the Guideline of GRI G4 Disclosure \\
& & Index. \\
\hline
\end{tabular}

Source: Empirical Survey (2021) 


\subsection{Model Specification and Justification}

The study adapted and modified the model of Mohammad and Aisa (2020) as shown below;

Mohammad and Aisa (2020): FV $=\beta_{0}+\beta_{1}$ CED $+\beta_{2}$ TI $+\beta_{3}$ PRO $+\beta_{4}$ LEV $+\mu \ldots \ldots . . .1$

The modified model for the study is shown as thus:

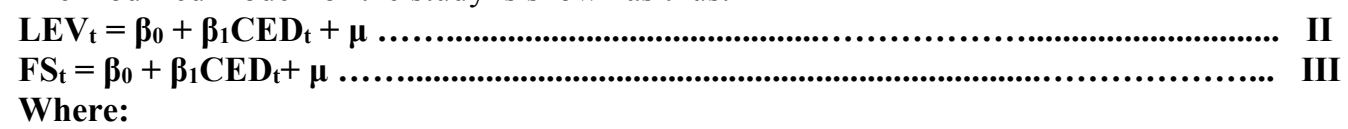

FV = Firm Value

$\mathrm{CED}=$ Carbon Emission Disclosures

PRO $=$ Profitability

LEV= Leverage

FS $=$ Firm Size

$\mu=$ error term

Decision Rule:

The generally expected criterion for decisions is stated below as:

Ho (null hypothesis) will be accepted if the P-value is greater than the $5 \%$ significant adopted as a standard and to be rejected where the $\mathrm{P}$-value is less than the $5 \%$ significant adopted. i.e. where $\mathrm{P}>5 \%$ we accept null hypothesis and where $\mathrm{P}<5 \%$, we reject null hypothesis.

\section{0: Data Presentation}

The data (i.e variables) needed for the study were shown on table 2 and were used in the data analysis of the study.

Table 2: The Data Summary of the 12 Oil \& Gas Firms Quoted on Nigerian Stock Exchange

\begin{tabular}{|c|c|c|c|c|c|}
\hline S/N & Company & Average & Carbon Emission Disclosures & Leverage & Log Firms Size \\
\hline 1 & Ardova Plc & $2015-2020$ & 0.8 & 0.6275 & 14.5300 \\
\hline 2 & Conoil Plc & $2015-2020$ & 2 & 0.7732 & 10.2485 \\
\hline 3 & Oando Plc & $2015-2020$ & 2 & 0.8092 & 14.1956 \\
\hline 4 & Japaul Oil Plc & $2015-2020$ & 0.8 & 1.3232 & 9.10848 \\
\hline 5 & Seplat Pet Plc & $2015-2020$ & 1 & 0.4150 & 13.8987 \\
\hline 6 & Total Oil PLc & $2015-2020$ & 1.3 & 0.7353 & 14.0875 \\
\hline 7 & Amino Intl Plc & $2015-2020$ & 0.9 & 0.1227 & 12.1850 \\
\hline 8 & Rak Unity Plc & $2015-2020$ & 1.1 & 0.6077 & 12.0735 \\
\hline 9 & Capital Oil Plc & $2015-2020$ & 0.9 & 0.6917 & 12.0445 \\
\hline 10 & 11 Plc & $2015-2020$ & 0.9 & 0.6357 & 11.9878 \\
\hline 11 & Mrs Oil Plc & $2015-2020$ & 2 & 0.6665 & 11.8907 \\
\hline 12 & Eternal Oil Plc & $2015-2020$ & 2 & 0.6550 & 11.9465 \\
\hline
\end{tabular}

Source: Compiled from the NSE Factbook and Annual Reports and Accounts of Oil \& Gas Firms on NSE for the year ended 2015-2020.

\section{1: Test of Hypotheses}

OLS Statistical Test Tool was developed to test the linear relationship between the dependent and independent variables. It was operated using SPSS version 20 as shown on the tables below:

Table 3: Result on effect of Carbon Emission Disclosures on Leverage of Oil and Gas Firms in Nigeria. Model Summary

\begin{tabular}{|c|c|c|c|c|c|c|c|c|c|c|}
\hline \multirow[t]{2}{*}{ Model } & \multirow[t]{2}{*}{$\mathrm{R}$} & \multirow{2}{*}{$\begin{array}{c}\mathrm{R} \\
\text { Square }\end{array}$} & \multirow{2}{*}{$\begin{array}{l}\text { Adjusted } \\
\text { R Square }\end{array}$} & \multirow{2}{*}{$\begin{array}{l}\text { Std. Error } \\
\text { of the } \\
\text { Estimate }\end{array}$} & \multicolumn{5}{|c|}{ Change Statistics } & \multirow{2}{*}{$\begin{array}{l}\text { Durbin- } \\
\text { Watson }\end{array}$} \\
\hline & & & & & $\begin{array}{l}\text { R Square } \\
\text { Change }\end{array}$ & $\begin{array}{c}\mathrm{F} \\
\text { Change }\end{array}$ & df1 & $\mathrm{df} 2$ & $\begin{array}{l}\text { Sig. F } \\
\text { Change }\end{array}$ & \\
\hline 1 & $0.760^{\mathrm{a}}$ & 0.680 & 0.650 & 1.0002 & 0.540 & 7.078 & 1 & 70 & 0.000 & $\mathrm{~b} 2.086$ \\
\hline
\end{tabular}

a. Predictors: (Constant), CEDs

b. Dependent Variable: LEV

\begin{tabular}{|c|c|c|c|c|c|c|c|}
\hline \multicolumn{8}{|c|}{ Coefficients $^{a}$} \\
\hline \multirow[t]{2}{*}{ Model } & \multicolumn{2}{|c|}{$\begin{array}{l}\text { Unstandardized } \\
\text { Coefficients }\end{array}$} & $\begin{array}{l}\text { Standardized } \\
\text { Coefficients }\end{array}$ & \multirow[t]{2}{*}{$\mathrm{t}$} & \multirow[t]{2}{*}{ Sig. } & \multicolumn{2}{|c|}{ Collinearity Statistics } \\
\hline & $\mathrm{B}$ & Std. Error & Beta & & & Tolerance & VIF \\
\hline $\begin{array}{ll}1 & \text { (Constant) } \\
\text { CEDs }\end{array}$ & $\begin{array}{r}.483 \\
-.678\end{array}$ & $\begin{array}{l}.409 \\
.351\end{array}$ & -.327 & $\begin{array}{l}5.083 \\
-4.823\end{array}$ & $\begin{array}{l}.000 \\
.000\end{array}$ & 1.000 & 1.000 \\
\hline
\end{tabular}

a. Dependent Variable: LEV 
Table 4: Result on effect of Carbon Emission Disclosures on the Size of Oil and Gas Firms in Nigeria. Model Summaryc

\begin{tabular}{|c|c|c|c|c|c|c|c|c|c|c|}
\hline \multirow[t]{2}{*}{ Model } & \multirow[t]{2}{*}{$\mathrm{R}$} & \multirow{2}{*}{$\begin{array}{c}\mathrm{R} \\
\text { Square }\end{array}$} & \multirow{2}{*}{$\begin{array}{c}\text { Adjusted } \\
\text { R } \\
\text { Square }\end{array}$} & \multirow{2}{*}{$\begin{array}{c}\text { Std. } \\
\text { Error of } \\
\text { the } \\
\text { Estimate }\end{array}$} & \multicolumn{5}{|c|}{ Change Statistics } & \multirow{2}{*}{$\begin{array}{l}\text { Durbin- } \\
\text { Watson }\end{array}$} \\
\hline & & & & & $\begin{array}{c}\mathrm{R} \\
\text { Square } \\
\text { Change }\end{array}$ & $\begin{array}{c}\mathrm{F} \\
\text { Change }\end{array}$ & df1 & $\mathrm{df} 2$ & $\begin{array}{l}\text { Sig. F } \\
\text { Change }\end{array}$ & \\
\hline 1 & $0.670^{\mathrm{a}}$ & 0.610 & 0.580 & .67000 & 0.530 & 20.436 & 1 & 70 & 0.000 & $\mathrm{~b}_{2.435}$ \\
\hline
\end{tabular}

\begin{tabular}{|c|c|c|c|c|c|c|c|}
\hline \multirow[t]{2}{*}{ Model } & \multicolumn{2}{|c|}{ Unstandardized Coefficients } & \multirow{2}{*}{$\begin{array}{c}\begin{array}{c}\text { Standardized } \\
\text { Coefficients }\end{array} \\
\text { Beta }\end{array}$} & \multirow[t]{2}{*}{$\mathrm{t}$} & \multirow[t]{2}{*}{ Sig. } & \multicolumn{2}{|c|}{ Collinearity Statistics } \\
\hline & $\mathrm{B}$ & Std. Error & & & & Tolerance & VIF \\
\hline $\begin{array}{ll}1 & \text { (Constant) } \\
\text { CEDs }\end{array}$ & $\begin{array}{l}.614 \\
.554\end{array}$ & $\begin{array}{l}.343 \\
.105\end{array}$ & .475 & $\begin{array}{l}3.246 \\
4.521\end{array}$ & $\begin{array}{l}.002 \\
.000\end{array}$ & 1.000 & 1.000 \\
\hline
\end{tabular}

a. Dependent Variable: FS

a. Predictors: (Constant), CEDs

b. Dependent Variable: FS

\section{2: Discussion of Findings}

The result of the analysis of the study using OLS Regression operated with SPSS version 20 is expressed as follows: H01: Carbon Emission Disclosure has no significant effect on Leverage of Oil and Gas Firms in Nigeria.

In view of the above analysis as shown on table 3, the results indicates that the relationship between Carbon Emission Disclosures and Firms Leverage is negative and significant with a P-value (significance) of 0.000 which is less than the $1 \%$ level of significance adopted. Likewise the result of negative coefficient of $-67.8 \%$ for the model is proving that an increase in firm's level of disclosure on Carbon Emission decreases firms leverage by $67.8 \%$. Thus implies that environmental friendly firms are equity intensive (less debt intensive). By this implication, environmentally friendly firms are more sustainable.

Based on this, we rejected the null hypothesis and accepted alternate hypothesis which contends that Carbon Emission Disclosure has significant effect on Firms Leverage. This agrees with the apriori expectations of Cucchiella, Gastaldi, and Miliacca (2017) and Omaliko and Okpala (2020) who found significant and positive relationship between the variables. Bae, Lee and Psaros (2013), Jannah and Muid (2014) and Anggraeni (2015) on the other hand found insignificant and negative relationship between carbon emission disclosures and firms performance.

Ho2: Carbon Emission Disclosure has no significant effect on the Size of Oil and Gas Firms in Nigeria.

In view of the above analysis as shown on table 4, the results indicates that the relationship between Carbon Emission Disclosures and Firms Size is positive and significant with a P-value (significance) of 0.000 which is less than the $1 \%$ level of significance adopted. This could be verified with the positive coefficient of $55.4 \%$ for the model which indicates that an increase in firm's level of disclosure on Carbon Emission as other variables are been held constant increases firms size by $55.4 \%$. Thus implies that environmental friendly firms are more sustainable than firms that are not environmental friendly. Also, the size of a firm is determined by its sustainability. This agrees with the Stakeholders Theory which states that the purpose of every firm is to make profit but the profit could not be attained or be attainable if the environment is been neglected.

Based on this, we rejected the null hypothesis and accepted alternate hypothesis which contends that Carbon Emission Disclosure has significant effect on Firms Size. This is in consonance with the findings of Jannah and Muid (2014) and Gallego-Álvarez, Segura, Martínez-Ferrero (2015) who found that carbon emission disclosure has significant and positive impact on firm size.

\subsection{Conclusion}

Global warming has been a major and topical issue that attracts attention and public concerns towards disasters it caused that could jeopardize the life of living creatures which remains a global burning issue. The increasing danger in global warming is driven by greenhouse gas emissions produced by human actions. However, corporate's carbon emission disclosures include community environment, business environment, and government pressuring the companies to respond to the threats of environmental sustainability resulting from the effects of extreme climate changes. Hence, the study from the statistical analysis concludes that Carbon Emission Disclosures have significant and positive effect on sustainability of oil and gas firms in Nigeria.

\section{2: Recommendation}

Based on findings of the study, the following recommendations are suggested: 
1. Since the study reported a significant association between carbon emission disclosures and firms leverage, it was recommended that corporate organizations should indulge on environmental practices since environmental friendly firms are more sustainable. Also, more of this information disclosure should be made available in the financial reporting of firms for financial information users' consumption. As such, the company is able to increase its stakeholders' confidence, which will also increase its business profit that ensures sustainability

2. Corporate organizations should also be social responsible since the study reported a positive and significant association between carbon emission disclosure and firms size. Also the study shows that sustainability of a company's current life is largely determined by the company's ability to manage economic performance and social performance. Hence, more of carbon emission disclosures should also be made available in financial reporting of firms since firm size is determined by its sustainability.

\section{References}

Akhiroh, T., \& Kiswanto, K. (2016), “The determinant of carbon emission disclosures", Accounting Analysis Journal 5(4), 326-336.

Anggraeni, D. Y. (2015), "Pengungkapan Emisi Gas Rumah Kaca, Kinerja Lingkungan,Dan Nilai Perusahaan", Jurnal Akuntansi Dan Keuangan Indonesia 12(2), 188-209

Bae, C., Lee, D., \& Psaros, J. (2013), “An analysis of Australian company carbon emission disclosures”, Pacific Accounting Review 25(1), 58-79.

Cucchiella, F., M. Gastaldi, \& M. Miliacca (2017), “The management of greenhouse gas emissions and its effects on firm performance", Journal of Cleaner Production 167 (1), 1387-1400.

Diah, I., \& Efita, F. (2016), " The effect of carbon emission disclosures and corporate social responsibility on the firms value with environmental performance as variable control", Research Journal of Finance and Accounting 7(9), 122-130

Donavan, G. (1984), "Legitimacy theory as an explanation for non-financial disclosures" Victoria University of Techno.

Ennis, C., Kottwitz, S., Lin., \& Markusson, N. (2012), "Exploring the relationships between carbon disclosure and performance in FTSE 350 companies", Working Paper.

Freeman, E. (1984). Stakeholders theory; theoretical perspective, New York: Harper and Row Inc.

Gallego-Álvarez, I., Segura, L., Martínez-Ferrero, J. (2015). Carbon emission reduction: The impact on the financial and operational performance of international companies. J. Clean. Prod. 103, 149-159.

Gayo, A., \& Vera, D. (2020). Determinants of carbon emission disclosures, Journal of Economics, Business, and Accountancy Ventura, 22(3), 333 - 346

Guthrie, J. \& Parker, L. (2009), "Corporate social reporting: A rebuttal of legitimacy theory" Accounting and Business Research 19(76): 343-352.

Healy, M., \& Krishna, G. (2001), "Information asymmetry, corporate disclosure, and the capital markets: A review of the empirical disclosure literature", Journal of Accounting and Economics 31 (1-3), 405-440.

Jannah, R., \& Muid, D. (2014), "Analisis faktor-faktor yang mempengaruhi carbon emission disclosure pada perusahaan di Indonesia (studi empiris pada perusahaanyang terdaftar di bursa efek Indonesia periode 20102012)", Diponegoro Journal of Accounting 3(2), 1-11.

Lee, K.., \& Min, B. (2015), "Green R\&D for eco-innovation and its impact on carbon emissions and firm performance", J. Clean. Prod 108, 534-542.

Mohammad, H., \& Aisa, T. (2020), “Analysis of carbon emission disclosures and firm value; type of industry as a moderating model”, International Journal of Scientific and Technology Research 9(2), 1125-1132

Mohammad, H., Aisa, T., \& Indah, P. (2020), "The effect of carbon emission disclosures on firms value; environmental performance and industry type", Journal of Asian Finance, Economics and Business 8(1), 123133

Omaliko, E., \& Okpala, N. (2020), "Effect of environmental disclosures on dividend payout of firms in Nigeria", International Journal of Banking and Finance Research 6(3), 14-28

Omaliko, E., Nweze, A., \& Nwadialor, E. (2020), "Effect of social and environmental disclosures on performance of non-financial firms in Nigeria", Journal of Accounting and Financial Management 6(1), 16-39

Omaliko, E., Nwadialor, E., \& Nweze, A. (2020), "Effect of non-financial disclosures on performance of nonfinancial firms in Nigeria" Journal of Accounting and Financial Management 6(1), 40-68

Raffaello, C., John, A., \& Max, H. (2013), "Low-carbon development: opportunities for Nigeria”, World Bank Publications

Riebeek, H. (2010), “Global Warming: Feature Articles”, Retrieved October 16, 2015, from http://earthobservatory.nasa.gov/Features/GlobalWarming/

Saka, C., \& Oshika, T. (2014), "Disclosure effects, carbon emissions and corporate value", Sustainability Accounting, Management and Policy Journal 5(1), 22-45 
Serrasqueiro, Z. S., \& Nunes, P. M. (2008), "Performance and size: Empirical evidence from Portuguese SMEs", Small Business Economics 31(2), 195-217.

Siregar, S., \& Refandi, B (2018), "Association between environmental disclosures with financial performance, environmental performance and firm value", Social Responsibility Journal 4(1), 180-193

Syed, S. F. (2013), "Relationship between financial leverage and financial performance: empirical evidence of listed sugar companies of Pakistan", Global Journal of management and Business Research Finance 13, (8), 33-39

Suchman, M. C. (1995), "Managing legitimacy: Strategic and institutional approaches", Academy and of Management Review 20 (3), 571-610.

World resources institute (2019), "Confronting a new reality", WRI Annual reports

\section{Authors Biography}

Omaliko Emeka is a staff of Accountancy Department, NAU. He holds B.Sc \& M.Sc in Accounting; both degrees from Anambra State University and Ph.D in Accounting. He is a Fellow Scholars Academy and Scientific Society (FSASS), Associate Member Nigerian Institute of Management, Associate Member Institute of Professional Managers and Administrators of Nigeria, Graduate Member Institute of Debt Recovery and Practitioners of Nigeria. He also holds Professional Diploma in Education from Nwafor Orizu College of Education Nsugbe and a registered member of Teachers' Registration Council of Nigeria (TRCN). Omaliko was the former Head of Department of Accountancy, Anambra State Polytechnic, Mgbakwu. He is an editor and reviewer of many local and international journals. At par, he has many publications to his credit both at local and international level

Onyeogubalu Ogochukwu is a staff of Accountancy Department NAU. She holds B.Sc in Accounting from UNN and M.Sc in Accounting from NAU. She also holds Postgraduate Diploma in Education from NTI, Kaduna State. Onyeogubalu was the former Head of Service Support at Stanbic IBTC Bank Plc, Ketu Branch, Lagos State. She is a Doctoral student of Accountancy Chukwuemeka Odumegwu Ojukwu University Igbariam Campus.

\section{Acknowledgement}

All the staff of Accountancy Department, Nnamdi Azikiwe University are highly acknowledged and appreciated for their positive contributions to this work. All authors whose works are used and cited in the study are also appreciated too for their earnest contribution in this work. 